\title{
Knowledge, risk perceptions and attitudes of nurses towards HIV in a tertiary care hospital in Mangalore, India
}

\author{
Anand Venugopal", A Basavaprabhu, B Unnikrishnan \\ From 17th International Symposium on HIV and Emerging Infectious Diseases (ISHEID) \\ Marseille, France. 23-25 May 2012
}

\section{Introduction}

Infectious diseases like HIV are on rise in developing countries like India which puts heavy burden on health care needs. Nurses have a key role and spend considerable time taking care of HIV positive patients admitted in hospitals. Hence a study was conducted in our hospital to have an insight into their knowledge about HIV, their apprehensions while taking care of such patients and their attitudes and willingness to take care of them.

\section{Methods}

It's a cross sectional study done among 200 nurses of KMC Hospital, Mangalore. They were given validated questionnaire comprising of 67 items which included knowledge of spread of HIV, universal precautions, risk perceptions and their attitudes towards HIV positive patients. Their responses were analysed using SPSS software.

\section{Results}

Of the 200 Nurses selected, 152 completed the questionnaire. Regarding knowledge of HIV transmission, the correct response for widely advertised modes of transmission were higher-sexual contact $97.4 \%$, vertical transmission $88.8 \%$. However, $11.2 \%$ did not know about mother to child transmission and $28.9 \%$ about transmission by breast feeding. $90.1 \%$ felt HIV could be transmitted by sharing of plates and $83.6 \%$ felt by mosquito bites.93.4\% knew about universal precautions and 78.3\% routinely practiced it. $80.3 \%$ were aware of post exposure prophylaxis.79.2\% described caring HIV Positives as rewarding, $86.5 \%$ were willing to assist operations on hiv

\footnotetext{
* Correspondence: anandvmanipal@gmail.com

Radiology at Kasturba Medical College Hospital, Mangalore, India
}

patients and $84.9 \%$ were willing conduct deliveries. $13.4 \%$ felt they have right to refuse caring HIV patients and $97 \%$ felt surgical patients need to be routinely tested for HIV.

\section{Conclusions}

This study demonstrates that there are deficiencies in knowledge about HIV and false beliefs exist among nurses about spread of HIV. There is need to improve awareness about HIV and HIV patient care through training programmes to clear misconceptions amongst Nurses so that HIV positive patients are not discriminated against and are treated without discrimination.

Published: 25 May 2012

doi:10.1186/1742-4690-9-S1-P68

Cite this article as: Venugopal et al:: Knowledge, risk perceptions and attitudes of nurses towards HIV in a tertiary care hospital in Mangalore, India. Retrovirology 2012 9(Suppl 1):P68.

Submit your next manuscript to BioMed Central and take full advantage of:

- Convenient online submission

- Thorough peer review

- No space constraints or color figure charges

- Immediate publication on acceptance

- Inclusion in PubMed, CAS, Scopus and Google Scholar

- Research which is freely available for redistribution

Submit your manuscript at www.biomedcentral.com/submit C Biomed Central

\section{Ciomed Central}

(c) 2012 Venugopal et al; licensee BioMed Central Ltd. This is an Open Access article distributed under the terms of the Creative Commons Attribution License (http://creativecommons.org/licenses/by/2.0), which permits unrestricted use, distribution, and reproduction in any medium, provided the original work is properly cited. 